\title{
Impacts of COVID 19 on Policy of Tertiary Education in Nigeria: The Case of Professional Diploma in Education Students of Federal College of Education
} Vol. 6, No. 1, 28-42, 202 e-ISSN:2518-6647
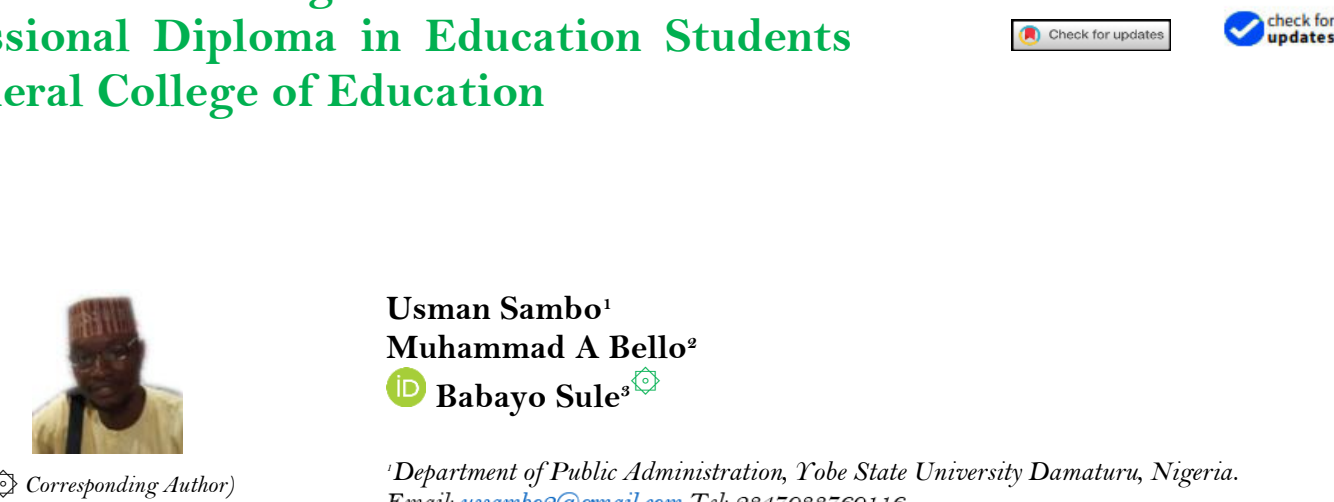

\author{
Usman Sambo ${ }^{1}$ \\ Muhammad A Bello \\ (iD) Babayo Sule ${ }^{\text {(2) }}$ \\ 'Department of Public Administration, Yobe State University Damaturu, Nigeria. \\ Email:ussambo2@gmail.com Tel:2347033760116 \\ Department of History, Gombe State University, Nigeria. \\ Email:muhammedbello50@gmail.com Tel:+2s48036577931 \\ ${ }^{-D e p a r t m e n t ~ o f ~ P o l i t i c a l ~ S c i e n c e, ~ F e d e r a l ~ U n i v e r s i t y ~ o f ~ K a s h e r e ~ G o m b e, ~ N i g e r i a . ~}$ \\ Email:babayosule@gmail.com Tel: +2347038653490
}

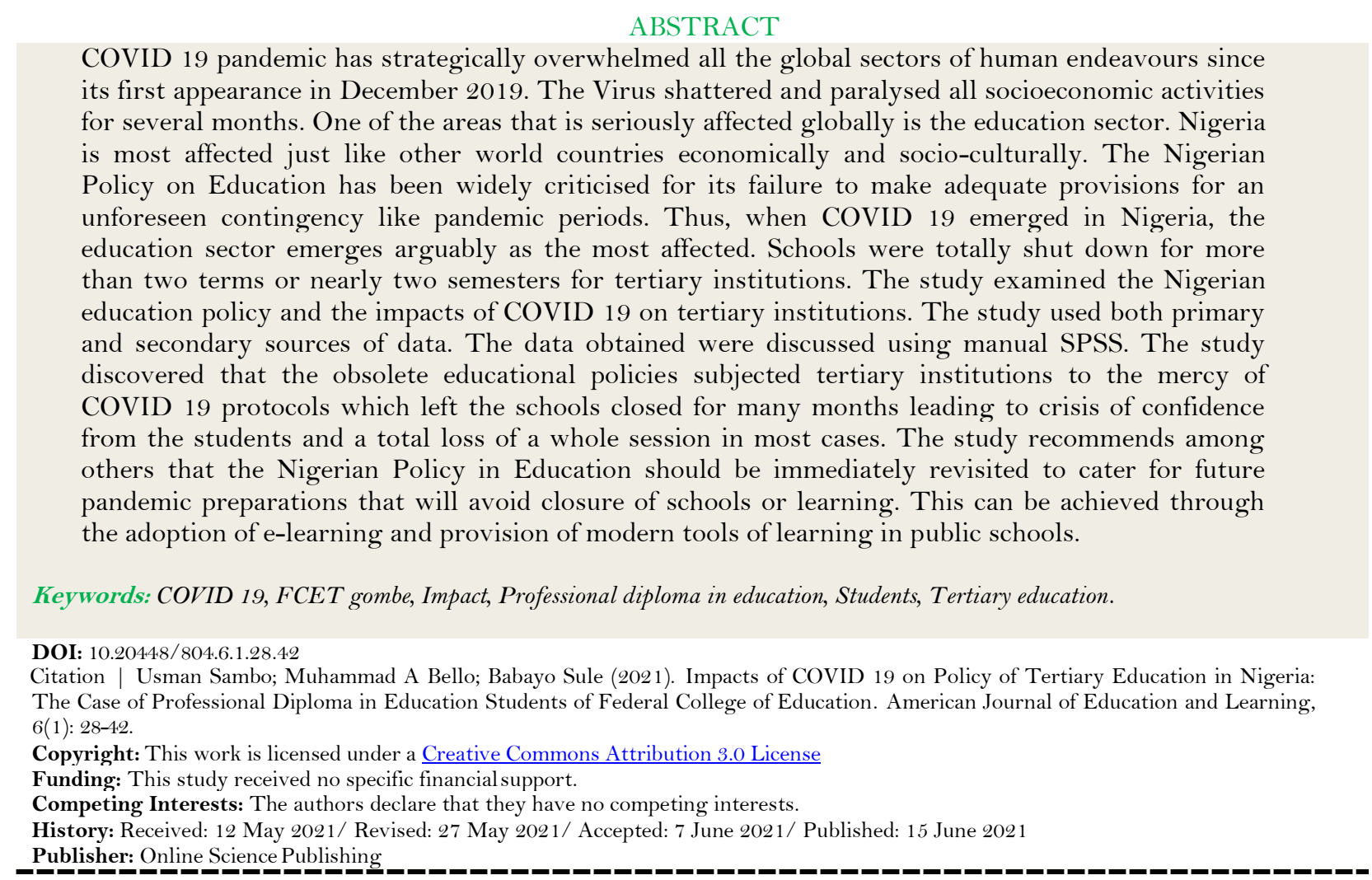




\section{Highlights of this paper}

- It investigated the perception of Nigerian students on how the COVID-19 affected educational policies with reference to tertiary institutions in terms of failure to provide adequate modern infrastructure leading to total closure for many months.

- The paper used a methodology that involved both primary and secondary sources with an adopted Elite Theory for explaining the context of the research.

- The research discovered that the Nigerian students are not happy with the current policy on tertiary Education and have blamed the poor preparation as the caused of their long stay at home during the COVID-19 lockdown.

\section{INTRODUCTION}

Pandemics are diseases that are regarded as new set of viruses that can easily become infectious and which have the tendency for a quick spread within short period of a time. Pandemics are regarded global or are identified as such if the rate of infection spread and fatalities become high, and efforts to overcome them prove difficult or costly for the global key players in health sector (Jarus, 2020). Usually, the World Health Organisation is the body that is saddled with the task of declaring a virus a pandemic in contemporary world. Pandemic differs from diseases and are given more attention because it is infectious and it claim lives easier than diseases which are sometimes personal and may not transcend beyond the carrier except if other contaminated processes such as blood transfusion and use of the same object are obtainable (World Health Organisation, 2020). In the case of a virus, it may spread as airborne, waterborne and through other means. In the history of the world, there are many pandemics which claimed heavy casualties including the Spanish Flu, HIV/AIDS, Ebola Virus Disease, Bird Flu, Zika and recently COVID 19. Some pandemics quickly spread worldwide while others are restricted in some areas (Live Science, 2020).

One of the devastating and fatal pandemics in the history of contemporary world is COVID 19. COVID 19 is a virus which emanated from the industrial city of Wuhan in China in December 2019 and is associated with difficulty in breathing, blocking of chest, severe cold and catarrh, severe fever and cough (Osler, 2020). The Virus is contacted through coming into contact with the infected persons either by mixing of breath, handshake or body contacts and even a close contact not necessarily a direct body contact. Within a short period of a time, the world was shock and paralysed in awe of the potential of the Virus in terms of number of novel cases, deaths and its spread worldwide. In less than two (2) months of the emergence of the Virus, it has nearly spread in all parts of the world. By January 2020, the WHO declared COVID 19 a global pandemic because it has been spreading quickly beyond Chinese borders into other parts of the world in an unprecedented speed (Zizek, 2020).

COVID 19 suspended the world in 2020 in terms of economic and sociocultural activities and even in political terms. Because of the nature of the global connectivity, the world became more disentangled owing to modern tools of international travels such as planes, speed boats and light trains which connected millions of people daily globally (Rosberg \& Knell, 2020). By March 2020, almost all the 195 countries of the world had their share of the COVID 19 cases. The ban on international travel, closure of schools, lock downs and suspension of social gatherings and international events started hitting the economy and social segments of the world (Hochberg, 2020). Economies collapsed, social gatherings or rather activities such as schooling, sports and international festivals were abruptly stopped while international and even domestic political activities were halted. The world was shocked and thrown into confusion (Hruby, 2020). The most annoying aspect of it all is that several medical researches were conducted but no positive response was attained throughout the year 2020 except an alternative of lock down and travel ban. Countries that are perceived as technologically advanced with modern facilities of healthcare system failed to arrest the Virus. America, Italy, Spain, England, Germany, India, Brazil, Iran, Mexico and South Africa were hit hard by the Virus leading to a global political economic shock (Samaddar, 2020). 
One of the major areas that are affected most by the effects of COVID 19 is the education sector. Within less than three months of the outbreak of the pandemic, closure of schools began worldwide even in the advanced countries that have for long adopted the use of technology and distance or digital learning for instructions and delivery (Campbell \& McCaslin, 2020). While the advanced countries later decided to continue with instructions through digital means, their educational system suffered a less blow than the developing countries who totally shut down their schools helplessly for almost an entire session. This scenario led to many critical comments and observations on the nature and level of the educational system in developing countries especially Africa where rich countries like Nigeria became helpless (International Monetary Fund, 2020).

Nigeria is one of the African countries that is hit hard by COVID 19. The first confirmed case was recorded in Lagos in March and because of the delay in taking adequate measures of ban on international travel and lock down, the Virus spread rapidly making cases in May serious that an inter-state travel was declared and a lock down was imposed. Suddenly, all economic and social activities in the country stopped. Schools were closed and learning was discontinued (Onwujekwe, Orjiakor, \& Agwu, 2020). The Nigerian educational system is for long in comatose because of underfunding, negligence of the policymakers and nonchalant attitudes towards the improvement of the system by the managers of the sector in addition to unqualified, unmotivated and an inadequate staffing (Amaghionyeodiwe \& Osinubi, 2006). Nigeria operates a 6334 education policy or system which is anticipated to give a compulsory basic education for all under the Universal Basic Education (UBE) and State Basic Education Board (SUBEB) in paper but in practice, the policymakers are not being serious about the sector for many decades. The outbreak of COVID 19 exposed the decay in the system which saw students helplessly sitting at home for almost a year. Despite the resumption of other activities, schools remained closed for good ten (10) months (Njoku, Ebiri, Olumide, Musa, \& Agboluaje, 2020).

Owing to the above background, this study examined the Nigerian Education Policy and how the COVID 19 Virus affected the tertiary education in Nigeria taking a specific case study of the Federal College of Education (Technical) Gombe (FCET). The study observed the setbacks caused by school closure taking the students of the Professional Diploma in Education (PDE) of FCET Gombe as a unit of analysis.

\section{LITERATURE REVIEW}

In this section, an attempt was made in reviewing related literature on the subject matter of study critically to justify the need for the research and to establish a contribution. Based on this, the following were discussed perspective on pandemics; a global view; overview of COVID 19 pandemic, COVID 19 pandemic in Nigeria, impacts of COVID 19 pandemic on Nigeria, the Nigerian Policy on Education, effects of COVID 19 pandemic on Nigerian tertiary education and background of Federal College of Education (Technical) Gombe. Additionally, a theory of was adopted and integrated in the work to explain more and support the concepts and issues discussed in the work.

\subsection{Overview of COVID 19 Pandemic}

COVID 19 is one of the major pandemics recorded in the history of the world. It is a virus which quickly spread and defied all forms of treatment in its early and even present stage. The Virus was transmitted through breath, handshake, face to face contact, body contact and through physical contact. The Virus emanated from an Industrial city of Wuhan in China with some certain symptoms of cold, catarrh, difficulty in breathing, severe fever and complications from the illness. Early efforts in responding towards the Virus by researchers failed to materialise in terms of presenting a breakthrough that will lead to an efficacious treatment or vaccination that will prevent it (World Health Organisation, 2020). 
In a blink of an eye, the Virus spread in all parts of China from Wuhan and because of the nature of global connectivity and technological breakthrough as well as innovation in modern transportation system, the Virus spread worldwide to the extent that by May 2020, almost all countries of the world recorded either confirmed cases or symptoms that are indicating towards that (Grant et al., 2020). The WHO officially declared the Virus a pandemic in January 2020. Many world countries started taking measures towards preventing and countering its spread. Researches were embarked upon in understanding the nature of the Virus and its treatment. However, a significant portion of 2020 was spent without any reliable breakthrough (He, Pan, \& Tanaka, 2020). World economies became comatose, social activities were halted, cultural interactions were abruptly stopped and international politics became heightened with tensions of allegations, accusations and counter-accusations among world leaders on the lukewarm attitude exhibited in curtailing the pandemic (Liang, 2020).

The COVID 19 pandemic as at 10 April, 2021 has confirmed cases of 135,804,081 (approximately one hundred and thirty-six million), 2,934,713 deaths, 23,617,864 active cases, 109,251,504 recovered cases and 112,186,217 closed cases (Worldometers, 2020). Countries that are most affected by the pandemic are USA, Brazil, China, Mexico, India, Italy, France, Spain, Iran, South Africa, Egypt, Russia, England, Nigeria and other high populous countries. The following table sample top ten (10) most affected as at the time of writing this research.

The WHO became busy finding a solution towards the management of the pandemic in terms of fund raising for intervention especially in the developing or weak economies. World countries resorted to ban on international travels particularly from the countries that are hit most by the pandemic such as China, USA, Brazil and India. Domestically, lock down was announced in many countries. Schools were closed and social gatherings of all forms including religious places of worship were all banned temporarily (Wang, Wang, Ye, \& Liu, 2020). The world became terrified and the search for a responsive treatment was made. The Virus continued to mesmerise the world until in the early 2021 when the vaccine for the Virus was developed. Still, the discovery of the vaccine is not seen as the guarantee for protection against contracting the Virus. Precautionary measures remain the major alternative to the pandemic.

\subsection{COVID 19 Pandemic in Nigeria}

The COVID 19 pandemic emerged and spread in Nigeria in 2020 precisely in the month of February. Most of the cases recorded in Nigeria resulted from the travelers who returned from abroad within the period. They may have contacted the virus from the departed destination, on aero plane or at arrival in the airport after intermingling with the carrier patients. Nigeria is the area of study (Attah, Sambo, Sule, Bello, \& Saragih, 2021). The country is located in West Africa and is one of the Sub-Saharan African countries. The country has a geographical land area in square kilometres of $983,213 \mathrm{~km}^{2}$. The approximate population of Nigeria is 200 million based on the projection of 2006 population census. The country is currently a federal state divided into six geopolitical zones and three tiers of government, Federal Capital Territory in Abuja (FCTA), 36 states and 774 local governments areas. Politically, Nigeria operates a presidential system of government with a bi-cameral legislature consisting of the Senate and House of Representatives. The country is neighbouring Niger Republic in the North, Benin Republic in the West, Chad in the North and Cameroon Republic in the South and North (Sambo \& Sule, 2021).

Nigeria is the most populous country in Africa, the seventh most populous country in the world, the tenth largest oil producing country and the biggest GDP in Africa above South Africa. Historically, Nigeria has three stages of evolution. An existence of kingdoms, chiefdoms, societies and organisations during pre-colonial period which lived independently but coordinately. The second historical epoch is the colonial period spanning the years between 1860 s to 1960 s in which the British colonisers occupied and colonised the territory known as Nigeria 
today. The third historical stage is the post-colonial period from 1960 to date. Nigeria has recorded several political, economic, social and cultural development and issues also in its self-rule years (Sule, 2018). The global health index in 2019 reported Nigeria as one of the countries with the low level of healthcare services. The report further suggested that Nigeria's health system is weak. This means the country may not be able to fight COVID 19 (Onwujekwe et al., 2020).

By March 26, Nigeria had already recorded over fifty (50) cases with one death from COVID. Most of the early symptoms or cases of COVID infection were reported from the Nigerian ruling class. Perhaps, this is because they are perceived as the privilege few that has the opportunities for international travels and exposure (Hruby, 2020). This submission seems valid because apart from the Chief of Staff to the President, Malam Abba Kyari, the son of former Vice President and the PDP Presidential in 2019 Candidate, Alhaji Atiku Abubakar was reported positive. Some state governors in Bauchi, Kaduna and Osun were also reported infectious. Initially, public perception of the disease was inimical and hostile. Many could not believe in the pandemic due to culture, religious influence, ignorance and loss of confidence in the political leadership of the country. It took a serious national re-orientation embarked by the media, intellectuals, religious clerics, royal fathers and the NCDC. The incidences of death reported in televisions from Spain, Italy, Iran and United States of America further helped swayed the public opinion to embrace the disease as real. This enabled for the government to secure enough support for taking the measures of response as discussed in the subsequent sections (Shaban, 2020).

The virus which was spreading slowly in Nigeria suddenly began to increase in index cases daily. From fifty (50) cases in March, Nigeria recorded 1, 300 cases by $29^{\text {th }}$ April with 40 deaths. This has been attributed to the low level of testing of the Nigerian population of 200 million in consideration. This is proved by the fact that Nigeria conducted just around 12, o0o tests as at $23^{\text {rd }}$, April while Botswana, a country with a population of $10 \mathrm{million}$ had conducted over 5, 000 and South Africa, with a population of around 50 million had conducted over 185, O0O around

that time (Campbell \& McCaslin, 2020). The situation revealed the weakness of the Nigerian response considering the way in which the numbers of index cases keep on rising daily in a geometrical scenario. By the end of May, Nigeria recorded over 8, 000 cases with more than 150 deaths (National Centre for Disease Control, 2021).

From the inception of the month of May, over 100 new cases are reported daily. This may not lack linkage with low response in terms of testing coverage and other related factors. Many infected persons might be roaming the Nigerian environment freely spreading the virus before detection and testing. To this end, this study anticipated that before the overcoming of the pandemic globally, which is unknown for now, Nigeria may report hundreds of thousands of cases or even a million or millions with thousands of deaths. This can be related to the negligence from the part of the government and the populace (Africa CDC, 2021). The government was hitherto, advised by health experts and other stakeholders to shut down the Nigerian border from international travels in January ending. However, because the children of the privileged ruling class and the ruling elites were abroad, the government failed to adopt this measure until late February when many of them returned affected. This has been established accurately if one considers the first set of the cases from the above report). The confirmed cases reported in Nigeria currently as at 10 April, 2021 is 1,803,177 samples tested, 163,652 confirmed cases, 2,059 deaths, 2, 697 deaths, 154,073 discharged cases and 7,520 active cases. States with the highest case are Lagos and Federal Capital Territory Abuja (FCTA) (National Centre for Disease Control, 2021).

\subsection{The Nigerian Policy on Education}

The responsibility of the Nigerian Policy on Education is manage by the two (2) tiers of government; the Federal and State Governments. Education in Nigeria is constitutionally perceived as a public enterprise pursued 
for a non-profit motive. Funding is expected from government at various levels. Education policy is formulated in Nigeria with a view to achieve the long-term goal of national development. Because of the paramount position of education in societal development, the Nigerian Government has been identifying and formulating policies on education since independence (Amaghionyeodiwe \& Osinubi, 2006).

The most comprehensive National Policy on Education was launched in 1977 which is anchored toward selfactualisation, personal and community efficiency, national unity and it targetted economic, political, social, cultural, scientific, technological development. The 1977 Policy was expanded in 1985 to have include free primary education. The Policy has undergone several review from time to time. The structure of the educational system in pre-1980s was six years for primary education, five to seven years in secondary education including Teachers College and four to six years of tertiary education involving Colleges of Education, Polytechnics, Universities and other related institutions (Amaghionyeodiwe \& Osinubi, 2006).

From 1984 upwards, the education system in Nigeria was restructured into 2 years for nursery school, 6 years for primary education, 3-year junior secondary education and 3-year senior secondary education followed by a 4year tertiary education. This system is known as 6334 which is still in operation in Nigeria. In 1999, the Obasanjo Administration introduced the Universal Basic Education (UBE) as a compulsory educational programme for all Nigerians which has the goal of providing a basic quality education up to the level of junior secondary school free. The state governments also adopted the same measure to complement the efforts of the Federal Government by introducing State Basic Education (SUBEB) (Amaghionyeodiwe \& Osinubi, 2006).

The Nigerian Government insists on undertaking the responsibility of education from basic to the tertiary levels with the governments at all levels involved actively in providing funding for running the affairs of the educational system in Nigeria. This is where the Nigerian educational system encountered its major problem. Gradually, as the country is unconsciously tilting towards capitalist system and it keeps on liberalising various sectors of the economy, education was not spared. The sector continues to suffer a huge deficit in terms of funding. Despite the granting of license for the private operators to run the education sector by allowing for the establishment of private schools from primary schools to universities, the Nigerian Government continues to sponsor education at various levels but with a nonchalant attitude toward funding (Amaghionyeodiwe \& Osinubi, 2006).

The UNESCO recommendation of a minimum of $26 \%$ of annual budget to be spend on education for developing countries like Nigeria was vehemently ignored. Allocation for education budget continues to decline year by year from 1990s. The military administration did better in terms of budget allocation because they had allocated more than two (2) digits for the sector since 1980s. from 1999, the situation deteriorated until when the allocation to education became around 5\%-6\% of the total budget in 2019 and 2020 respectively. The infrastructure became dilapidated, teaching profession became for underdogs with low pay, lack of regular promotion, withholding of allowances, delay in training and above all, violation of global best practices of teacher-student ratio. This is the situation that the system found itself when the COVID 19 emerged in Nigeria. This is the reason why the Nigerian educational system suffered a huge blow and a setback during the period of lock down because there are practically no facilities on round to warrant for digital learning (Ahmed, 2020).

\subsection{Impacts of COVID 19 on Tertiary Education in Nigeria}

COVID 19 successfully exposed the decay in the Nigerian educational system. Initially, the Virus shocked the world that all schools were immediately closed globally. Schools in countries that took the business of education serious have been transforming and taking their learning into digital arena because of the provision of modern 
facilities of learning including audio-visual mechanisms, internet, computers and virtual library. When many countries realised that there is a possibility the pandemic may stay beyond expectation and the lock down and travel ban are extended continuously, they resorted to learning at home which was carried out using a digital process (Ahmed, 2020). In Nigeria, facilities for digital learning are not provided to even the teachers in the education system talk less of students who are learning (Okuwa, 2004).

One of the greatest impacts of COVID 19 on tertiary education in Nigeria is the total shut down of schools without any alternative for learning at home. Instead, the governments at various levels and non-governmental organisations identified learning by radio as a temporary alternative which failed to work as expected. How could one teach Mathematics, Physics, Geography, Chemistry, Biology and many other subjects using a descriptive analytics from a radio? The radio learning is seen as a progress since it was not thought of before but it was short of meeting the need for avoiding waste of time under lock down at home. Schools remain closed for six months from May till November and in the case of public universities, for over ten months due to the ritual Academic Staff Union of Universities (ASUU) strike which commenced since January (Hruby, 2020). It should be noted that even the learning by radio just covered basic levels of education; primary and secondary. The tertiary institutions were left out of it because it is practically impossible.

Another impact of COVID 19 on tertiary education in Nigeria is the destabilisation of the academic calendar. Schools were shut down for a whole semester or even two semesters were missed out during the process of the lock down. This situation automatically generated a natural repeat and a one-year delay for hundreds of thousands of students. Many schools especially tertiary institutions reviewed their calendar and start afresh after the relaxation of the lock down. This situation emanated from the failure of the government to provide modern facilities of learning and equipment which would have granted the teachers and the students an easier means of learning at home (Campbell \& McCaslin, 2020).

Furthermore, COVID 19 affected the tertiary education by shortening the period of study which deprived the students from acquiring the minimum needs of the period before transition to another stage. After the lift on lock down and re-opening of schools, many schools decided to crash their programmes by running a whole semester in six weeks. In this condition, students cannot grasp the basic that is expected to be covered in three months just in one month especially that they are not use to it in any circumstance. In the case of private schools, they collected parents' money and allocated results as they wish to meet the term requirements without the students learning anything concrete. This scenario further stretched the tertiary educational system because it will escalate the production of half-baked graduates on top of the already existing ones which will not augur well for the country in future (Wren-Lewis, 2020).

Additionally, COVID 19 affected the tertiary education in Nigeria economically. The Nigerian education system is an economic driver which generates lots of business opportunities and economic activities when the session is active. In schools and campuses, businesses worth millions are operated across Nigeria. With the closure, the business stopped leading to economic shock. The Nigerian Government as part of its social investment programme introduced home grown feeding for primary school pupils which is a multi-billion Naira economic activity. The food vendors in thousands are employed for the feeding while the dealers are supplying the foodstuff worth billions. The closure of schools affected this economic activity. Although, the Government later declared that it continued with the programme, it was just seen as a corruption model of the elites since it was difficult to reach out to pupils and feed them while under lock down (Onyekwena \& Ekeruche, 2020).

Besides, COVID 19 compelled for the closure of Nigerian schools without an alternative but some private schools in the country utilised a digital means to continue with their instructions. This saved them of missing an 
entire calendar year. The development diminished drastically the peoples' confidence in government and they have become cynical of the sabotage by their rulers. Many individuals in Nigeria started questioning the rationale behind the gross underfunding and deplorable situation of our public schools making them to start developing the thinking of a country without a government practically because of their failure in discharging their responsibility as expected (Olufemi, 2020).

\subsection{Background of Federal College of Education (Technical) Gombe}

The Federal College of Education (Technical) Gombe was formerly known as National Technical Teachers College which was established in 1977 with the sole mandate of producing teachers with specialisation in technical, vocational and science qualification for primary and secondary schools in the country. The College commenced it activities in temporary site in Gombe Crafts School under the headship of a principal. The relocation to the permanent site began in 1989 and it was accomplished in 1996. The College was during that time directly under the supervision of the Federal Ministry of Education until when the Federal College of Education Establishment Decree No.4 of $21^{\text {st }}$ March, 1984. The College gained an autonomy under its current name of Federal College of Education (Technical) Gombe. The College is situated in Ashaka Road, Gombe with a land area covering about 325.92 hectares (Federal College of Education (Technical) Gombe, 2018).

The regulatory body for FCET Gombe and other colleges of education is National Commission for Colleges of Education (NCCE) which accredit courses and supervise quality control in the College. The FCET Gombe is currently running several courses including National Certificate in Education (NCE), Diploma in Education, Degree Programmes and Continuing Education. Some of the courses are distance learning with an affiliation from some universities such as University of Maiduguri and Abubakar Tafawa Balewa University Bauchi (Federal College of Education (Technical) Gombe, 2018).

The FCET Gombe consists of many schools among which there are School of Education which hosts the following Courses: Department of General Studies, Department of Educational Foundation and Management, Department of Curriculum and Instructional Technology and Department of Psychology and Guidance and Counselling. The School of Business Education has Courses such as Department of Psychology and Guidance and Counselling and Secretarial Education Department. The School of Primary Education has departments including Arts and Social Sciences Department, Languages and Literacy, Primary Sciences and Vocational Education. The School of Science Education has many departments such as Biology Department, Computer Science, Chemistry Department, Integrated Science and Mathematics Department. The School of Technical Education has many departments including Automobile Technology Department, Building Technology Department, Electrical/Electronic Technology Department, Metal Work Technology Department and Woodwork Technology Department. The School of Agriculture has a Department of Agricultural Education, Soil Science, Crop Production, Animal Husbandry and Fisheries and Livestock. The School of Preliminary studies provides a programme on PreNCE (Federal College of Education (Technical) Gombe, 2018).

Apart from the above major courses, the FCET Gombe offers other courses either on part-time basis or continuing education. This include Degree in various courses in affiliation with. University of Maiduguri and ATBU. The College also offers Postgraduate Diploma in Education (PGD) and Professional Diploma in Education (PDE). The College also provides some consultancy services including certificate in Computer and Diploma known as GOFCECON. The College has approximately 20,000 students and staff strengths of over 7,000 with many PhD holders and qualified staff that have experience for teaching (Federal College of Education (Technical) Gombe, 2018). 


\subsection{Theoretical Framework}

The study adopted Elite Theory in explaining the nature, causes and consequences of rulers' negligence of the Nigerian educational system leading to the current predicament when the COVID 19 emerged in the country. The Elite Theory came into being in the 1930s from the Italian Sociologists (Michel, 1949; Mosca, 1939) and Political Scientist (Ortega, 1932). The Theory assumed that society is divided into two main groups: the elite and the masses. Unlike the Marxist' contradiction and antagonism, Elite Theorists postulated that there is a harmony because the elite is coordinated, organised, intellectual and skilful in manipulating their way into power in the society. The minority few elite class is influential in decision making, power control because they are politically developed and economically advanced. Through the prowess of political and economic power, they tend to dominate politics in the society using some shrewd process. Michel (1949) advanced that the 'Iron Hand of Oligarchy' is sometimes necessary to compel obedience and support by the elite against the masses.

One of the fundamental pillars of societal development and which has been found expedient in propelling members of the society towards political education is education itself. Nigerian elites are not interested in giving the citizens of the country a sound education that will prepare them for a better political organisation. Since the elites secure power using dirty political tricks such as rigging, manipulation, vote buying, ethnic, religious and regional sentiments, they are comfortable with an ignorant population which can be easily manipulated. This is the reason why they continue to neglect the education sector and by extension, deliberately starve the sector from adequate funding. The elites devised an alternative for their children since many decades by granting license for private schools to operate where they take their children to get a more qualitative educational training than the children of the masses. When they have realised that the private schools in Nigeria are not satisfactory to them, they resorted to taking their children abroad for a first class educational training at the expenses of the poor that they are claiming to be governing.

This theory is a good explanation of the subject matter of study. This is because if the elites or ruling class are serious and are sincere in delivering the trust which is given to them by the electorates, they should have considered the plight of education sector after several researches and investigations by experts in the country pointed to a decay and collapse in the area. Furthermore, if their children are schooling in public schools, they will never allow the sector in its rotten state as it is today. Also, if they are curious and serious about an enlightened society for national development, they will not have been neglecting the sector the way it is. This is the reason why this study saw the process that led to the despicable condition in the education sector as an elite manipulation. This is the major reason why the COVID 19 pandemic devastated the sector beyond redemption since a whole session is lost in many cases while in other cases, the terms or semesters are managed in a crash programme which skipped many parts of the curriculum all which will have negative impacts on the overall development of the country in future.

\section{METHODOLOGY}

The study is a survey method which gather information from some selected members of the area of study, FCET Gombe and generalised the findings. A sample is taken from the area of study based on systematic method and the method adopted is the quantitative method of data collection and analysis. This is because it is the most suitable in a study of this nature. For a survey of peoples' opinion on a subject matter that is academic in nature, using an interview or sampling of views is the best. This is the reason why this study adopted a quantitative technique. 
The data were sourced from both primary and secondary sources. The primary source is a type of data which was obtained from the field work. After the identification of the targetted respondents in the research, an instrument was designed for data collection and the targetted audience were consulted to have their views or perception on the topic of research. The secondary type of data was obtained from the existing literature on the subject matter. This include books, journal articles, media sources both printed and electronics and internet sources. The data obtained in this category are used for the review of literature and formation of theoretical framework.

The study area is Federal College of Education (Technical) Gombe which is reported to have a population of about 20,000 students. For the sake of feasibility of study and for accuracy and validity of the study, the chosen or selected sample from the is considered based on what the researcher can cover according to the financial strength, time limit and capability. The sample of the study is the total number of the PDE students, 2019/2020 session which is 19 for the fully registered students in the Centre for Continuing Education. Factors considered in choosing the sample is the size and number. Since 1929 as a number can conveniently represent 20,000 according to Taro Yamane's formula, the whole class is chosen. This is quite easy and feasible for the researcher because questionnaire distribution is easier since all members of the class are connected in a WhatsApp group making for distribution and collection less tasking for the researcher. However, 117 responded.

The instrument for data collection is the questionnaire administration. Some set of close-ended questions were asked and the respondents were asked to tick accordingly based on their perception or views. The questionnaire was designed based on the objectives of the research. The tool used for gathering of the data was the social media platform of WhatsApp where the questionnaire was placed on the platform of the PDE students of 2019/2020 session for their responses. The filled and completed ones were collected later from the same group. The method adopted for data analysis is the Special Package for Social Sciences (SPSS). The manual SPSS was used where the responses are grouped into tabular form for an analysis using simple percentage. The outcome was used for discussions and findings.

\section{DISCUSSIONS AND FINDINGS}

This section presented the data obtained from the field, discussed them and interpreted them for findings.

4.1. Presentation of Data and Analysis

Table-1. Characteristics of the Respondents.

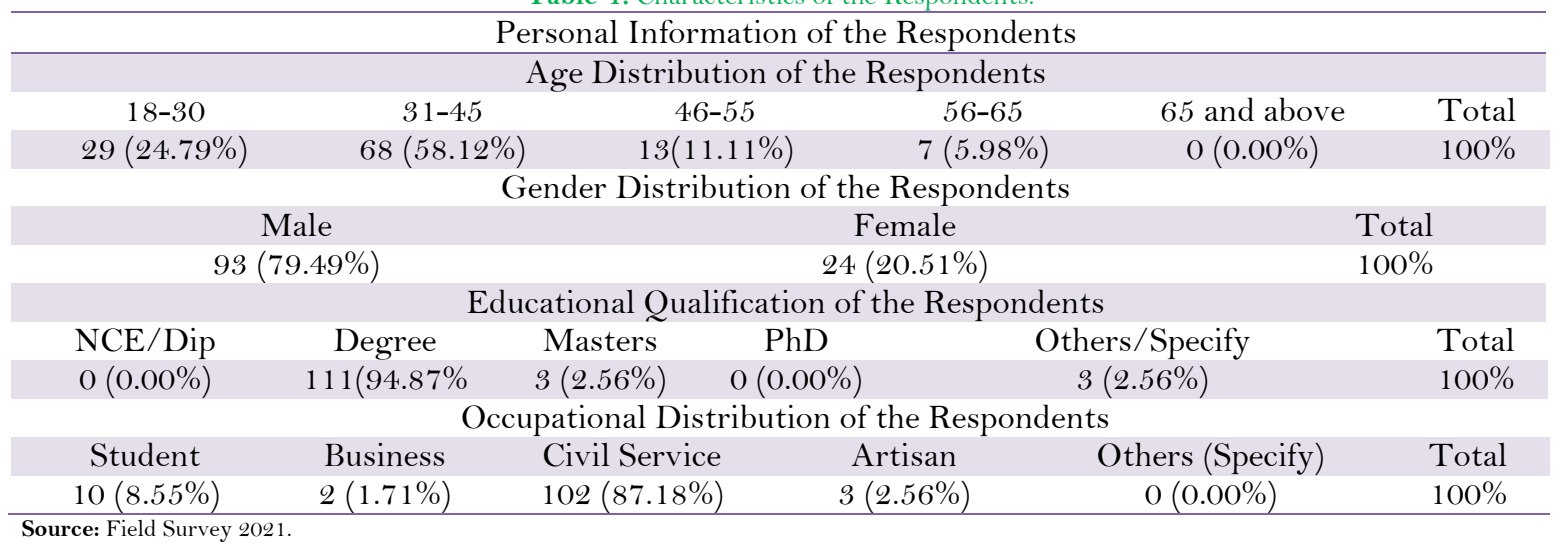

The age of the respondents disclosed that most of them are within the age bracket of middle age based on Nigerian life expectancy of 58 years. In the category $18-30$ years, 29 (24.79\%) falls in this category. It is discovered 
that $68(58.12 \%)$ constitutes those who falls within the age category of 31-45. In the age category of $46-55,13$ $(11.11 \%)$ falls within this age group. In the age category of 56-65, 7 (5.98\%) falls within this age group while 0 $(0.00 \%)$ of the respondents falls within the age category of 65 years and above. This means that most or all of the respondents are within the active age of civil service and are either advancing their studies for their professional career or for their proposed future career.

The gender distribution of the respondents indicates that majority of the members or students in PDE class is male gender. The distribution shows that $93(79.49 \%)$ of the respondent is male while $24(20.51 \%)$ of the respondents is female. There are three reasons here why the distribution appeared in this way. One is may be the bulk of those who did not responded might be female gender who are more occupied with household activities and could not get chance to respond via social media. The second reason is may be male gender is dominant in the admitted students of the PDE class of 2019/2020 session. Another reason is the one that can lead to generalisation meaning that the overall number of male gender is more than female gender in the College in general.

The above table is the educational qualification of the respondents. The distribution shows that there is no NCE/Diploma in the class. There is 111 (94.87\%) Degree holders, 3 (2.56\%) Masters holders, o PhD holder and 3 $(2.56 \%)$ HND holders. It is not surprising because most of the class members from the sample population are either graduate teachers who came in search of a minimum qualification for teaching as a profession or are interested in furthering their education in the education field even if they are not teachers. This may not give a good representation of the students in the College in general because most of them are NCE students but it will give the Degree holders some fair representation because they now constitute a significant number in the College owing to Distance Learning Programme and other programmes related to it.

Table-2. Responses of the Interviewers on the Impacts of COVID 19 on tertiary education Nigeria.

\begin{tabular}{|c|c|c|c|c|c|c|}
\hline S/No. & $\begin{array}{l}\text { Research Questions } \\
\text { and Objectives }\end{array}$ & & & Responses & & \\
\hline \multirow[t]{2}{*}{1.} & \multirow{4}{*}{$\begin{array}{l}\text { Students' perception } \\
\text { of COVID } 19 \text { as a } \\
\text { global pandemic } \\
\text { Measures taken for } \\
\text { personal protection }\end{array}$} & Agreed & Disagreed & Undecided & & Total \\
\hline & & $97(82.91 \%)$ & $\begin{array}{c}6 \\
(5.13 \%)\end{array}$ & $14(11.97 \%)$ & & $117(100 \%)$ \\
\hline \multirow[t]{2}{*}{2.} & & $\begin{array}{l}\text { Social } \\
\text { isolation }\end{array}$ & $\begin{array}{c}\text { Social } \\
\text { distancing }\end{array}$ & $\begin{array}{l}\text { Facemask } \\
\text { and hand } \\
\text { sanitiser }\end{array}$ & $\begin{array}{l}\text { Reporting } \\
\text { symptoms } \\
\text { to NCDC }\end{array}$ & Total \\
\hline & & $31(26.50 \%)$ & $19(16.24 \%)$ & $56(47.86 \%)$ & $\begin{array}{c}11 \\
(9.40 \%)\end{array}$ & $117(100 \%)$ \\
\hline \multirow[t]{2}{*}{3.} & \multirow{2}{*}{$\begin{array}{l}\text { Perception on why } \\
\text { tertiary institutions } \\
\text { in Nigeria schools } \\
\text { remained closed for } \\
\text { over six months }\end{array}$} & Govt. failure & $\begin{array}{l}\text { Lack of } \\
\text { facilities }\end{array}$ & $\begin{array}{c}\text { Safety } \\
\text { measures }\end{array}$ & $\begin{array}{c}\text { Unsafe } \\
\text { environment }\end{array}$ & $\begin{array}{l}\text { Inadequate } \\
\text { preparation }\end{array}$ \\
\hline & & $63(53.85 \%)$ & $38(32.48 \%)$ & $\begin{array}{c}7 \\
(5.98 \%)\end{array}$ & $\begin{array}{c}4 \\
(3.42 \%)\end{array}$ & $\begin{array}{c}5 \\
(4.27 \%)\end{array}$ \\
\hline \multirow[t]{2}{*}{4.} & $\begin{array}{l}\text { Measures such as } \\
\text { learning by radio are } \\
\text { they adequate? }\end{array}$ & Yes & No & Undecided & & Total \\
\hline & & $32(27.35 \%)$ & $82(70.09 \%)$ & $\begin{array}{c}3 \\
(2.56 \%)\end{array}$ & & $117(100 \%)$ \\
\hline \multirow[t]{2}{*}{5.} & \multirow[t]{2}{*}{$\begin{array}{l}\text { The extent in which } \\
\text { schools closure } \\
\text { affected } \\
\text { education }\end{array}$} & $\begin{array}{l}\text { Graduation } \\
\text { delay }\end{array}$ & $\begin{array}{c}\text { Crash } \\
\text { programme }\end{array}$ & $\begin{array}{l}\text { Missing } \\
\text { curriculum }\end{array}$ & $\begin{array}{c}\text { Loss of a } \\
\text { whole } \\
\text { session }\end{array}$ & $\begin{array}{l}\text { Economic } \\
\text { losses \& loss } \\
\text { of confidence } \\
\text { in leadership }\end{array}$ \\
\hline & & $50(42.74 \%)$ & $24(20.51 \%)$ & $16(13.68 \%)$ & $\begin{array}{c}11 \\
(9.40 \%)\end{array}$ & $\begin{array}{c}16 \\
(13.67 \%)\end{array}$ \\
\hline
\end{tabular}


The occupational distribution of the respondents shows that $102(87.18 \%)$ of them are civil servants, $2(1.71 \%)$ is a group of businessmen, $3(2.56 \%)$ falls in the category of artisans, $10(8.55 \%)$ is a group of students. This means that most of the students in that class are civil servants. It cannot be said of the same in the other classes especially pre-NCE and NCE students. However, a good number of pre-NCE and NCE students are nowadays married.

There are several controversies, misperceptions and contradictions on the existence and impact of COVID 19 as a global pandemic. In this study, 97 (82.91\%) of the respondents agreed that there is COVID 19 as a pandemic, 6 $(5.13 \%)$ disagreed that it is just a political economic interplay of global forces while 14 (11.97\%) remained silent without taking any position on the matter. This means that majority, a large significant percentage believed in COVID 19 as a pandemic because you have to believe in the pandemic to think of its impacts and other issues related to it. This is because most of the class members are educated and are exposed to world intrigues and histories of pandemics. If the research focus on other groups such as people in the rural areas or those that have not attended any formal school, the turnover of the responses may possibly be different from what is obtained here.

From the above table, the respondents were asked on measures that they have taken to protect themselves from infecting COVID 19, they responded in the following way. 31 (26.50\%) of the respondents used social isolation, 19 (16.24\%) resorted to social distancing, $56(47.86 \%)$ adopted the use of facemask and hand sanitiser while $11(9.40 \%)$ reported any symptom that they felt or saw from immediate neighbours to the NCDC for prevention. This means that most of the class members preferred to continue to relate in public except that they are using the means of facemask and hand sanitiser. This can be interpreted that should the school give an option for closure or continuation with classes under protection measures, majority will have chosen the option of continuation with classes.

The respondents were asked on their understanding of why the Nigerian schools were closed during the first wave of COVID 19 pandemic, their responses are analysed below. Out of the total of 117,63 (53.85\%) perceived government failure in taking the full of responsibility of providing the sector with adequate resources as the main reason, $38(32.48 \%)$ attributes the reason for the closure on lack of modern facilities of learning, 7 (5.98\%) mentions safety measures as the reason probably to avoid the spread of the virus, 4 (3.42\%) indicates that poor environment of learning is the reason while $5(4.27 \%)$ sees the reason as inadequate preparation for countering the virus. From the above responses, it is clear that about $100(85 \%)$ of the respondents agreed that failure of the government and lack of modern facilities which are all related are the major reasons why the schools were closed during the first wave of COVID 19 pandemic.

The respondents were asked a question on whether the alternative learning by radio introduced by government and other organisations during the closure of school was useful or not, the respondents provided the following answers. Out of the total of 117,32 (27.35\%) agreed, 82 (70.09\%) disagreed while $3(2.56 \%)$ remains silent. By interpretation, this means that most of the respondents do not perceive learning by radio as a substitute or an attempt that will alleviate the long stay at home. This perhaps, has to do with the time of the programme which not all are available, level of comprehension and mode of instruction especially of some subjects with numerical illustration are difficult to be delivered using listening instruction only without any form of visual display.

When the respondents were asked on their perception of how the closure of school affected the university system, they responded differently as follows. Out of the total of $117,50(42.74 \%)$ admitted that it led to delay in graduation, 24 (20.51\%) expressed that it caused crash programme, $16(13.68 \%)$ believed that many parts of the curriculum were missed in the process, $11(9.40 \%)$ expressed that a whole session is missed, $16(13.67 \%)$ agreed that 
it led to economic losses and loss of confidence in the leadership of the country because the situation exposed how vulnerable the education system is and how negligent the government is.

\section{FINDINGS}

It is discovered that the COVID 19 pandemic has many impacts on Nigerian educational system in many ways. In the first place, the pandemic brought about several views from different individuals. The study found that like in other aspects of life, many students and those in the education sector have a variant view on the nature or even existence of the virus itself. This has been supported by some studies (Campbell \& McCaslin, 2020; Hruby, 2020) that perception on COVID 19 pandemic is still controversial in Nigeria. The study also discovered that most of the respondents preferred the use of protection method such as wearing of facemasks and washing of hands with hand sanitisers. Majority did not subscribe to the idea of social exclusion or isolation as reported also by some studies (Ahmed, 2020; Olufemi, 2020). In addition, the study found that most of the respondents blamed the Nigerian Government for its negligence in addressing the rot in the education system. They perceived that the government failed to provide adequate funding and because of that, the education sector could not get the required modern facilities that will survive the pandemic in terms of continuation of studies. This same situation was also reported by studies (Attah et al., 2021; Sambo \& Sule, 2021).

\section{CONCLUSION AND RECOMMENDATION}

The study concludes that there is a well-organised system of education in Nigeria which is reviewed periodically to ensure that it is updated to cater for any new development. However, the system remains just a mere paper work since the government totally neglected the public schools and deliberately orchestrated the process of their decay and rot by underfunding and offering of license for the private schools to operate. Also, once the ruling elites realised the essence of taking their children abroad for study, they finally finished the remnants of the quality in public schools by abandoning it. The government is only visible in public schools when it comes to contracts of building classrooms and halls for a kickback. There is no adequate compensation for the teachers, no modern facilities such as internet and functional libraries and other relevant materials of modern learning. The study concludes that COVID 19 pandemic emerged and met the education sector in Nigeria handicapped and in a deplorable situation to the extent that it failed to survive the process which left the country with the only alternative of closing schools to avoid the spread of the Virus.

The study made some recommendations following the findings and revelations from the investigations that took place. One of the recommendations is that government must provide adequate funding for education sector and it must also supply all the needed modern facilities of learning that can survive the occurrence of a future event like COVID 19 and beyond. The above recommendation can be realised if all public office holders whether elected or appointed and civil servants enroll their children in school which will be the only way to compel the policymakers to discharge their duty of providing quality education for national development. Additionally, people should take their rights beyond mere verbal or social media analysis. They should engage those that are seeking for elective offices to ensure that they strike deal with them for providing some essential services such as education, health, security and others. This can be done by avoiding money politics or vote buying and asking the contestants to sign an agreement towards that with the electorates. Furthermore, all stakeholders must put hands in desk to rescue the education sector in Nigeria. Philanthropers should provide funding, alumni should be engaged by their schools for source of fund, corporations and other organisations should be engaged towards providing means of funding to 
complement for what the government cannot provide. This is because education is not only the business of government but all members of the society alike.

\section{REFERENCES}

Africa CDC. (2021). Corona virus disease 2019 (COVID 19). African Union. Retrieved from https://africacdc.org/covid-19/. [Accessed 29th March, 2021 at 10:05 pm].

Ahmed, M. (2020). COVID 19 and Nigerian educational system: Whither alternative? Paper presented at the a 2-Day Workshop on Education for National Development in Transcorp Hilton Hotel Abuja 3rd-4th November, 2020.

Amaghionyeodiwe, L., \& Osinubi, T. (2006). The Nigerian educational system and returns to education. International Journal of Applied Econometrics and Quantitative Studies, 3(1), 31-40.

Attah, N. E., Sambo, U., Sule, B., Bello, M. A., \& Saragih, M. Y.(202 1). COVID 19 and increased security challenges in Northern Nigeria: Interrogating Armed Banditry in Northwestern Nigeria. SIASAT, 6(1), 33-44. Available at: https://doi.org/10.33258/siasat.v6i1.87.

Campbell, J., \& McCaslin, J. (2020). How Nigeria has responded to COVID-19 so far. Council on foreign relations. Retrieved from https://www.cfr.org/blog/how-nigeria-has-responded-covid-19-so-far. [Accessed 28th March, 2021 at 8:47 $\mathrm{pm}]$.

Federal College of Education (Technical) Gombe. (2018). Students Handbook (2018-2020). Gombe: FCET Press.

Grant, W. B., Lahore, H., McDonnell, S. L., Baggerly, C. A., French, C. B., Aliano, J. L., \& Bhattoa, H. P. (2020). Evidence that vitamin D supplementation could reduce risk of influenza and COVID-19 infections and deaths. Nutrients, 12(4), 988. Available at: https://doi.org/10.3390/nu 12040988

He, G., Pan, Y., \& Tanaka, T. (2020). COVID-19, City lockdowns, and air pollution: Evidence from China. medRxiv. Available at: https://doi.org/10.1101/2020.03.29.20046649.

Hochberg, M. (2020). Importance of suppression and mitigation measures in managing COVID-19 outbreaks. Retrieved from: https://www.medrxiv.org/content/10.1101/2020.03.31.20048835v3.

Hruby, A. (2020). A rough road ahead for Nigeria: Atlantic council. Lagos: Atlantic Council.

International Monetary Fund. (2020). IMF executive board approves US $\$ 3.4$ Billion in emergency support to Nigeria to $\begin{array}{lllll}\text { address } & \text { COVID-19 } & \text { Pandemic. } & \text { IMF. }\end{array}$ https://www.imf.org/en/News/Articles/2020/04/28/pr20191-nigeria-imf-executive-board-approves-emergencysupport-to-address-covid-19. [Accessed 29th March, 2021 at 10:48 pm].

Jarus, O. (2020). 20 of the worst epidemics and pandemics in history. Retrieved from https://www.livescience.com/worstepidemics-and-pandemics-in-history.html. [Accessed 29th March, 2021 at 10:19 pm].

Liang, T. (2020). Handbook of COVID 19 prevention and treatment. Zhejiang, China: Zhejiang University of Medicine.

Live Science. (2020). Spanish flu: The deadliest pandemic in history. Retrieved from https://www.livescience.com/spanishflu.html. [Accessed 28th March, 2021 at 8:50 pm].

Michel, R. (1949). First lectures in political sociology. New York: Harper TouchBook.

Mosca, G. (1939). The ruling class. Michigan: University of Michigan Press.

National Centre for Disease Control. (2021). COVID 19 Nigeria. Abuja: Federal Government of Nigeria.

Njoku, L., Ebiri, K., Olumide, S., Musa, N., \& Agboluaje, R. (2020). Why controversy over FG's COVID-19 palliatives persists. The Guardian Nigeria. Retrieved from: https://guardian.ng/news/why-controversy-over-fgs-covid-19-palliativespersists/. [Accessed 12th June 2021 at 9:54 pm].

Okuwa, O. B. (2004). Private returns to higher education in Nigeria. African Economic Research Consortium Research Paper No. 139. Nairobi, March. 
Olufemi, J. (2020). Nigeria budgets N2,000 for the healthcare of each citizen in 2020. Premium Times. Retrieved from https://www.premiumtimesng.com/health/health-features/361373-nigeria-budgets-n2000-for-the-healthcare-ofeach-citizen-in-2020.html. [Accessed 29th March, 2021 at 10:54 pm]

Onwujekwe, O., Orjiakor, C., \& Agwu, P. (2020). Coronavirus: Corruption in health care could get in the way of Nigeria's response' the conversation. Retrieved from https://theconversation.com/coronavirus-corruption-in-health-care-couldget-in-the-way-of-nigerias-response-136913. [Accessed 15 May 2020].

Onyekwena, C., \& Ekeruche, A. (2020). Understanding the impact of the COVID-19 outbreak on the Nigerian economy. Brookings. Retrieved from https://www.brookings.edu/blog/africa-in-focus/2020/04/08/understanding-the-impactof-the-covid-19-outbreak-on-the-nigerian-economy/. [Accessed 29th March, 2021 at 10:56 pm].

Ortega, Y. G. (1932). The revolt of masses. New York: W.W. Norton \& Company Inc.

Osler, S. (2020). Corona virus outbreak. Revealed all secrets about COVID 19 pandemic. complete rational guide it's evolution, expansion, symptoms and first defense. US: Sidney Publishers.

Rosberg, A. G., \& Knell, R. G. (2020). How will this continue? Modelling interactions between the COVID-19 Pandemic and policy responses. London, UK: Queen Mary University of London.

Samaddar, R. (2020). Introduction: Borders of an epidemic. In Samaddar, R. (Ed.), Borders of An Epidemic: COVID-19 and Migrant Workers. Calcutta, India: Mahanirban Calcutta Research Group.

Sambo, U., \& Sule, B. (2021). COVID 19 and national security challenges in Africa: Analysing the responses towards countering Armed Banditry in Northwestern Nigeria. Journal of Conflict Resolution and Social Issues, 1(2), 1-17.

Shaban, A. A. (2020). Nigeria coronavirus: 4,399 cases, Wike Demolishes Hotel, Kaduna Busts escapees. Africanews. Retrieved from https://www.africanews.com/2020/05/31/nigeria-coronavirus-hub-updates-covid-19/.

Sule, B. (2018). Political party financing and election reformations in Nigeria's 2015 general election: Issues and impacts. PhD Thesis Submitted to the School of International Studies, College of Law Government and International Studies, Ghazali Shafie Graduate School of Government, Universiti Utara Malaysia (2018).

Wang, L., Wang, Y., Ye, D., \& Liu, Q. (2020). Review of the 2019 novel coronavirus (SARS-CoV-2) 297 based on current evidence. International Journal of Antimicrobial Agents, 55(6), 1-8. Available at: https://doi.org/10.1016/j.ijantimicag.2020.105948.

World Health Organisation. (2020). African countries move from COVID 19 readiness to response as many confirm cases. WHO Africa. Retrieved from https://www.afro.who.int/health-topics/coronavirus-covid-19. $[$ Accessed 29th June, 2020 at $10: 26 \mathrm{pm}]$.

Worldometers. (2020). COVID 19 Corona virus pandemic: Corona virus cases. Retrieved from https://www.worldometers.info/coronavirus/. [Accessed 29th March, 2021 at 10:50 pm].

Wren-Lewis, S. (2020). The economic effects of a pandemic. In Baldwin, R. \& Weder Di Mauro, B. (Eds.), Economics in the Time of COVID-19 (pp. 109-112). London, UK: Centre for Economic Policy Research.

Zizek, S. (2020). Pandemic COVID 19 shakes the world. New York: OR Books.

Online Science Publishing is not responsible or answerable for any loss, damage or liability, etc. caused in relation to/arising out of the use of the content. Any queries should be directed to the corresponding author of the article. 